\title{
Desulfotomaculum thermosubterraneum sp. nov., a thermophilic sulfate-reducer isolated from an underground mine located in a geothermally active
} area

\author{
Anna H. Kaksonen, ${ }^{1}$ Stefan Spring, ${ }^{2}$ Peter Schumann, ${ }^{2}$ \\ Reiner M. Kroppenstedt ${ }^{2}$ and Jaakko A. Puhakka ${ }^{1}$
${ }^{1}$ Institute of Environmental Engineering and Biotechnology, Tampere University of Technology, Tampere, Finland \\ ${ }^{2} \mathrm{DSMZ}$ - German Collection of Microorganisms and Cell Cultures, Braunschweig, Germany
}

Correspondence

Anna H. Kaksonen

\begin{abstract}
A thermophilic, Gram-positive, endospore-forming, sulfate-reducing bacterium was isolated from an underground mine in a geothermally active area in Japan. Cells of this strain, designated RL50 $\mathrm{JIII}^{\top}$, were rod-shaped and motile. The temperature range for growth was $50-72^{\circ} \mathrm{C}$ (optimum growth at $61-66^{\circ} \mathrm{C}$ ) and the $\mathrm{pH}$ range was $6 \cdot 4-7 \cdot 8$ (optimum at $\mathrm{pH} 7 \cdot 2-7 \cdot 4$ ). Strain RL5OJIII tolerated up to $1.5 \% \mathrm{NaCl}$, but optimum growth occurred in the presence of $0-1 \% \mathrm{NaCl}$. Electron acceptors utilized were sulfate, sulfite, thiosulfate and elemental sulfur. Electron donors utilized were $\mathrm{H}_{2}$ in the presence of $\mathrm{CO}_{2}$, alanine, various carboxylic acids and alcohols. Fermentative growth occurred on lactate and pyruvate. The cell wall contained mesodiaminopimelic acid and the major respiratory isoprenoid quinone was menaquinone 7 (MK-7). Major whole-cell fatty acids were iso- $\mathrm{C}_{15: 0}$, iso- $\mathrm{C}_{17: 0} \mathrm{DMA}$ (dimethyl acetal), iso- $\mathrm{C}_{15: 0} \mathrm{DMA}$ and iso- $\mathrm{C}_{17 \text { :0. }}$. Phylogenetic analysis based on $16 \mathrm{~S}$ rRNA gene sequence comparisons revealed $98.7 \%$ similarity with Desulfotomaculum solfataricum DSM $14956^{\top}$. However, DNA-DNA hybridization experiments with Desulfotomaculum kuznetsovii, Desulfotomaculum luciae and $D$. solfataricum and the $\mathrm{G}+\mathrm{C}$ content of the DNA (54.4 mol\%) allowed the differentiation of strain RL50 $\mathrm{JII}^{\top}$ from the recognized species of the genus Desulfotomaculum. Strain RL50 $\mathrm{JIII}^{\top}$ therefore represents a novel species, for which the name Desulfotomaculum thermosubterraneum sp. nov. is proposed. The type strain is RL50JIII ${ }^{\top}\left(=\right.$ DSM $16057^{\top}=$ JCM $\left.13837^{\top}\right)$.
\end{abstract}

Sulfate-reducing bacteria comprise a diverse group of prokaryotes that contribute to the biogeochemical cycling of sulfur in many environments. Most of the described thermophilic sulfate-reducers belong to the cluster of Gram-positive, spore-forming Desulfotomaculum species (Goorissen et al., 2003). The genus Desulfotomaculum was first described by Campbell \& Postgate (1965). At the time of writing, the genus comprises 15 thermophilic species: $D$. alkaliphilum (Pikuta et al., 2000), D. arcticum (Vandieken et al., 2006), D. australicum (Love et al., 1993), D. carboxydivorans (Parshina et al., 2005), D. geothermicum (Daumas et al., 1988), D. kuznetsovii (Nazina et al., 1989), D. luciae (Liu et al., 1997), D. nigrificans (Werkman \& Weaver, 1927; Campbell \& Postgate, 1965), D. putei (Liu et al., 1997),

\footnotetext{
Abbreviation: DMA, dimethyl acetal.

The GenBank/EMBL/DDBJ accession number for the 16S rRNA gene sequence of strain RL50JIII ${ }^{\top}$ is DQ208688.

A phase-contrast micrograph of cells of strain RL50 $\mathrm{JIII}^{\top}$ is available as supplementary material in IJSEM Online.
}

'D. salinum' (Nazina et al., 2005), D. solfataricum (Goorissen et al., 2003), D. thermoacetoxidans (Min \& Zinder, 1990), D. thermobenzoicum with two subspecies, namely subsp. thermobenzoicum and subsp. thermosyntrophicum (Tasaki et al., 1991; Plugge et al., 2002), D. thermocisternum (Nilsen et al., 1996) and D. thermosapovorans (Fardeau et al., 1995). Recently, we reported the enrichment and isolation of thermophilic sulfate-reducers from an underground mine in a geothermally active area in Japan (Kaksonen et al., 2006). This paper describes a novel thermophilic, sulfatereducing bacterium, strain RL50JIII $^{\mathrm{T}}$, isolated from the mine.

Strain RL50JIII ${ }^{\mathrm{T}}$ was isolated from a geothermal mine site $250 \mathrm{~m}$ below ground, from a black sediment layer beneath a thin red layer of ferric iron on a tunnel wall. Temperature at the site was $70-80^{\circ} \mathrm{C}$. For comparisons, reference of $D$. kuznetsovii DSM $6115^{\mathrm{T}}$, D. luciae DSM $12396^{\mathrm{T}}$ and D. solfataricum DSM $14956^{\mathrm{T}}$, were obtained from the Deutsche Sammlung von Mikroorganismen und Zellkulturen (DSMZ, Braunschweig, Germany). 
Enrichment and isolation of strain RL50JIII ${ }^{\mathrm{T}}$ were performed at $50{ }^{\circ} \mathrm{C}$ using modified Postgate growth medium (pH 7·0-7·5) (Kaksonen et al., 2006) with lactate as the electron donor. Anaerobic roll-tubes solidified with $1 \cdot 5 \%$ agar were used for the isolation. For chemotaxonomic analysis and DNA isolation, the strain was cultured at $60{ }^{\circ} \mathrm{C}$ in modified DSM medium 641 containing lactate as the electron donor. The medium was supplemented with $1 \mathrm{ml}$ selenate-tungstate solution $1^{-1}$ (DSM medium 385) and sodium dithionate $\left(25 \mathrm{mg} \mathrm{l}^{-1}\right)$ was used as the reducing agent instead of $\mathrm{Na}_{2} \mathrm{~S}$.

The isolate was examined by phase-contrast microscopy (Axioskop 2; Zeiss) and photomicrographs were obtained using the agar slide technique as described by Kaksonen et al. (2004). Flagellum staining was performed as described by Heimbrook et al. (1989). Spore formation by the strain was examined microscopically and also by testing for growth after heat treatment $\left(95^{\circ} \mathrm{C}\right.$ for $\left.25 \mathrm{~min}\right)$. The Gram type of the cells was determined by both Gram staining and the KOH test (Gregersen, 1978).

The effects of temperature, $\mathrm{pH}$ and $\mathrm{NaCl}$ concentration on growth were determined as previously described (Kaksonen et al., 2006). The ability of the strain to utilize various electron donors (1-20 mM) was tested in medium containing $20 \mathrm{mM}$ sulfate. The utilization of various electron acceptors $(10 \mathrm{mM})$ was studied using lactate $(10 \mathrm{mM})$ as electron donor. Amorphous iron(III) oxyhydroxide was formed by neutralizing $\mathrm{FeCl}_{3}$ solution to a $\mathrm{pH}$ of 7 with $\mathrm{NaOH}$. The cultures were incubated for 1-2 weeks. Electron donor utilization was determined as bacterial growth (optical density at $660 \mathrm{~nm}$, Shimadzu UV-1601 spectrophotometer, or Ultrospec II LKB Biochrom 4050 UV/visible spectrophotometer), hydrogen sulfide production or substrate conversion. Hydrogen sulfide production was determined spectrophotometrically and substrate conversion by GC as previously described (Kaksonen et al., 2004). Ferrous iron was determined colorimetrically (UV-1601; Shimadzu) with ferrozine (Stookey, 1970). Concentrations of sulfate, sulfite, thiosulfate, nitrate and nitrite were determined by ion chromatography (DX-120; Dionex).

Cell wall preparations were obtained by boiling cells in $20 \%$ $(\mathrm{w} / \mathrm{v})$ aqueous trichloroacetic acid solution for $20 \mathrm{~min}$. Diaminopimelic acid isomers were detected in cell-wall hydrolysates $\left(4 \mathrm{M} \mathrm{HCl}, 100^{\circ} \mathrm{C}, 16 \mathrm{~h}\right.$ ) by TLC on cellulose sheets (Merck) using the solvent system of Rhuland et al. (1955). Respiratory isoprenoid quinones were extracted and analysed according to the methods described by Collins \& Jones (1981), Monciardini et al. (2003) and Groth et al. (1996) using an HPLC apparatus (Shimadzu) fitted with a reversed-phase C18 column $[150 \mathrm{~mm} \times$ $4.6 \mathrm{~mm}$ (ID), $5 \mu \mathrm{m}$, porosity $90 \AA$; Vydac] with UV detection at $269 \mathrm{~nm}$. The identity of the quinones was verified by GC-MS (GCMS-QP2000; Shimadzu) using direct injection with a temperature increase of $60-250^{\circ} \mathrm{C}$ at $35^{\circ} \mathrm{C} \mathrm{min}^{-1}$.
Fatty acid methyl esters of cellular fatty acids were obtained by saponification, methylation, extraction and base wash, as described by Kämpfer \& Kroppenstedt (1996), Kroppenstedt (1985) and Miller (1982). The fatty acid methyl mixtures were separated by use of a gas chromatograph (5890 Series II; Hewlett Packard) equipped with a Hewlett Packard Ultra2 (cross-linked $5 \%$ PH ME Siloxane) capillary column $(25 \mathrm{~m} \times 0.2 \mathrm{~mm} \times 0.33 \mu \mathrm{m}$ film thickness; HP Part No. 19091B - 102).

Methods for the amplification, sequencing and phylogenetic analysis of $16 \mathrm{~S}$ rRNA genes were as described previously (Kaksonen et al., 2006). Genomic DNA for G + C content determination and DNA-DNA hybridization experiments was released by rupturing cells using a French pressure cell (Thermo Spectronic) and then purified by chromatography on hydroxyapatite (Cashion et al., 1977). DNA was hydrolysed with P1 nuclease and the nucleotides dephosphorylated with bovine alkaline phosphatase (Mesbah et al., 1989). The G $+\mathrm{C}$ content of the resulting deoxyribonucleosides was determined by reversed-phase HPLC (Shimadzu) and calculated from the ratio of deoxyguanosine $(\mathrm{dG})$ and thymidine (dT) (Tamaoka \& Komagata, 1984; Mesbah et al., 1989). DNA-DNA hybridization experiments were performed at DSMZ according to the method of De Ley et al. (1970) with the modifications described by Huß et al. (1983), Escara \& Hutton (1980) and Jahnke (1992) using a spectrophotometer (model 2600; Gilford) equipped with a thermoprogrammer and plotter (model 2527-R; Gilford).

Cells of strain RL50JIII ${ }^{\mathrm{T}}$ were straight or slightly curved rods, $0 \cdot 8-1 \cdot 0 \mu \mathrm{m}$ in diameter and $3-10 \mu \mathrm{m}$ in length (see Supplementary Fig. S1 in IJSEM Online). The strain formed spherical spores, which were located centrally or subterminally. The spores were able to germinate after a heat shock at $95^{\circ} \mathrm{C}$ for $25 \mathrm{~min}$. Sporulation caused swelling of the cells, giving them a lemon-shaped appearance. The cells were motile with two or more flagella and Gram-positive as determined by both Gram-staining and the $\mathrm{KOH}$ test. The temperature, $\mathrm{pH}$ and $\mathrm{NaCl}$ ranges for growth of strain RL50JIII $^{\mathrm{T}}$ are given in Table 1. The temperature at the sampling point was $70-80^{\circ} \mathrm{C}$, which is at or above the upper temperature limit of growth of strain RL50JIII ${ }^{\mathrm{T}}$. It is possible that the strain was present in the habitat as spores. Strain RL50JIII ${ }^{\mathrm{T}}$ was able to use sulfate, sulfite, thiosulfate and elemental sulfur as electron acceptors. Electron donors utilized by the strain included $\mathrm{H}_{2}$ in the presence of $\mathrm{CO}_{2}$, alanine and various carboxylic acids, or their sodium salts, and alcohols (Table 1). A number of electron donors (e.g. propionate, butyrate, pentanoate, pyruvate, butanol, ethanol, lactate, isobutyrate, 2-methyl butyrate and succinate) were oxidized to acetate, whereas no acetate accumulated during the oxidation of others (e.g. alanine, hexadecanoate and nonanoate). The strain fermented lactate and pyruvate.

The cell wall of strain RL50JIII ${ }^{\mathrm{T}}$ contained mesodiaminopimelic acid as the diagnostic diamino acid and the major respiratory isoprenoid quinone was menaquinone 7 (MK-7). The whole-cell fatty acid compositions of strain 
Table 1. Characteristics of strain RL50 $\mathrm{JII}^{\top}$ compared with those of its closest relatives in the genus Desulfotomaculum

Taxa: 1, strain RL50JIII ${ }^{\mathrm{T}}$; 2, D. solfataricum (data from Goorissen et al., 2003); 3, D. kuznetsovii (Nazina et al., 1989); 4, D. luciae (Liu et al., 1997); 5, D. thermobenzoicum subsp. thermobenzoicum (Tasaki et al., 1991); 6, D. thermoacetoxidans (Min \& Zinder, 1990); 7, D. geothermicum (Daumas et al., 1988); 8, D. thermocisternum (Nilsen et al., 1996); 9, D. australicum (Love et al., 1993); 10, 'D. salinum' (Nazina et al., 2005). All taxa shared the following characteristics: rod-shaped cells, spore formation, sulfate $(10 \mathrm{mM})$ reduction, utilization of $\mathrm{H}_{2} / \mathrm{CO}_{2}$ $(80: 20, \mathrm{v} / \mathrm{v})$ as sole electron and carbon source, and oxidation of lactate $(20 \mathrm{mM})$. Strain RL50JIII ${ }^{\mathrm{T}}$ did not utilize nitrite or iron(III) as electron acceptors (each $10 \mathrm{mM}$ ), or tartrate, glutamate, mannose, galactose, sucrose, cellobiose, myo-inositol, lactose or trehalose (each $10 \mathrm{mM})$, phenylacetate $(3 \mathrm{mM})$, 4-hydroxybenzoate $(2 \mathrm{mM})$, tetradecanoate or dodecanoate (each $1 \mathrm{mM})$ as electron donors. The concentrations for electron donors, electron acceptors and fermentation given in the table apply only to the present study. +, Positive; - , negative; NR, not reported.

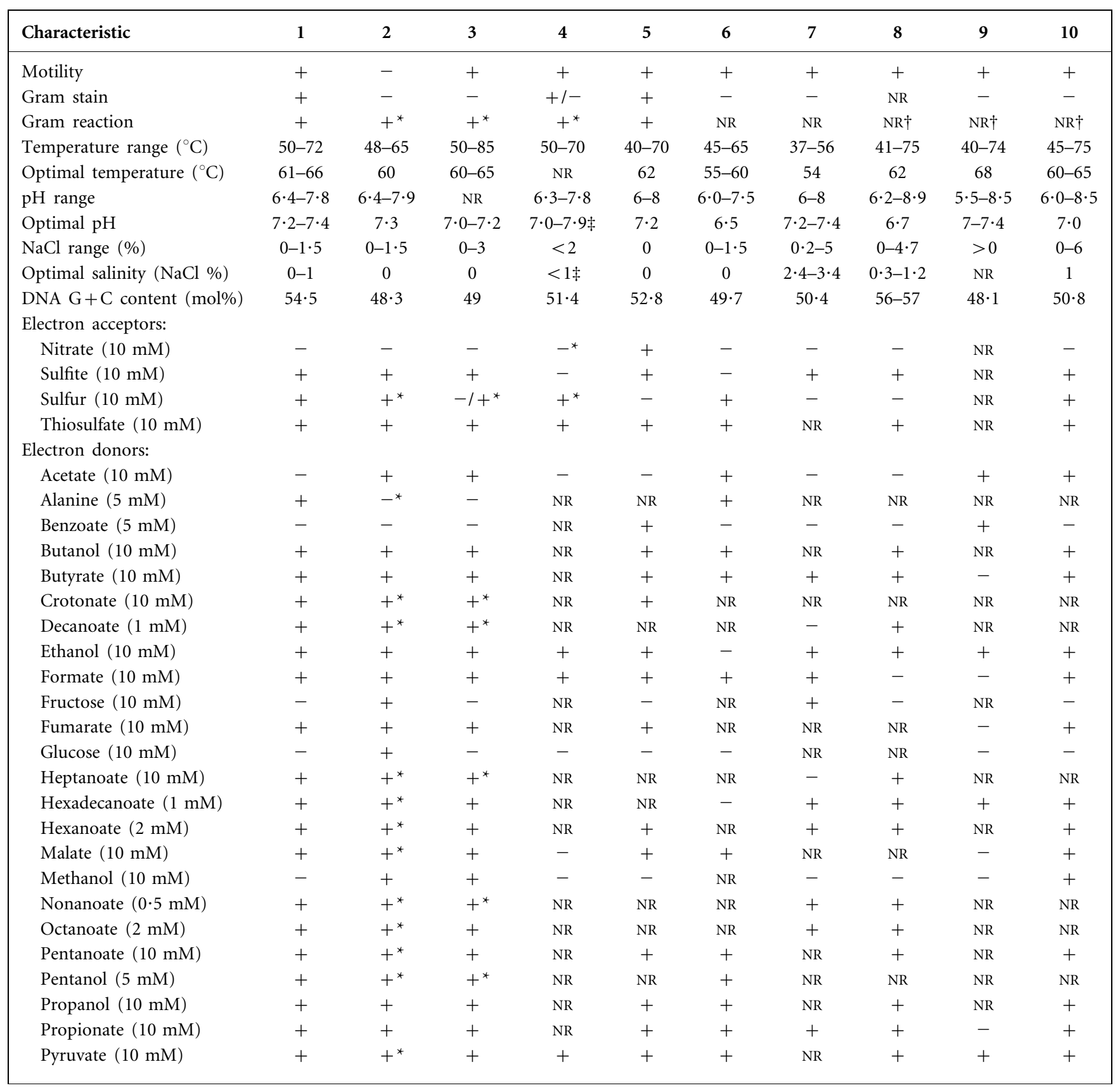


Table 1. cont.

\begin{tabular}{|c|c|c|c|c|c|c|c|c|c|c|}
\hline Characteristic & 1 & 2 & 3 & 4 & 5 & 6 & 7 & 8 & 9 & 10 \\
\hline Succinate $(10 \mathrm{mM})$ & + & + & + & NR & - & + & NR & NR & - & + \\
\hline \multicolumn{11}{|l|}{ Fermentation: } \\
\hline Lactate $(20 \mathrm{mM})$ & + & + & + & + & + & - & NR & NR & + & - \\
\hline Pyruvate $(10 \mathrm{mM})$ & + & $+^{*}$ & + & + & + & + & NR & + & + & + \\
\hline
\end{tabular}

${ }^{\star}$ Determined in this study.

$\nmid$ Gram-positive cell wall based on microscopic examination.

$\$$ Data obtained from Nazina et al. (2005).

RL50JIII $^{\mathrm{T}}$ and related species are presented in Table 2. Significant proportions of saturated iso-branched fatty acids were found in strain RL50JIII ${ }^{\mathrm{T}}$, the major components being iso- $\mathrm{C}_{15: 0}$, iso- $\mathrm{C}_{17: 0} \mathrm{DMA}$ (dimethyl acetal), iso- $\mathrm{C}_{15: 0}$ DMA and iso- $\mathrm{C}_{17: 0}$ (Table 2).

Table 2. Whole-cell fatty acid content of strain RL50JIII compared with reference species of the genus Desulfotomaculum

Taxa: 1, strain RL50JIII ${ }^{\mathrm{T}}$; 2, D. solfataricum; 3, D. kuznetsovii; 4, D. luciae. All data are from this study. Values shown are percentages of the total whole-cell fatty acids. -, Not present; ECL, equivalent chain length; DMA, dimethyl acetal; $c$, cyclopropane.

\begin{tabular}{|c|c|c|c|c|c|}
\hline ECL & Fatty acid & 1 & 2 & 3 & 4 \\
\hline $12 \cdot 62$ & iso- $\mathrm{C}_{13: 0}$ & $0 \cdot 1$ & - & - & - \\
\hline $13 \cdot 62$ & iso- $\mathrm{C}_{14: 0}$ & - & $0 \cdot 1$ & $0 \cdot 2$ & $0 \cdot 1$ \\
\hline $14 \cdot 00$ & $\mathrm{C}_{14: 0}$ & $1 \cdot 1$ & $2 \cdot 5$ & $2 \cdot 4$ & $0 \cdot 8$ \\
\hline $14 \cdot 48$ & $\mathrm{C}_{14: 0} \mathrm{DMA}$ & $0 \cdot 1$ & - & - & - \\
\hline $14 \cdot 63$ & iso- $\mathrm{C}_{15: 0}$ & $49 \cdot 6$ & $43 \cdot 2$ & $36 \cdot 5$ & $39 \cdot 3$ \\
\hline $14 \cdot 71$ & anteiso- $\mathrm{C}_{15: 0}$ & - & $1 \cdot 0$ & $0 \cdot 9$ & $0 \cdot 9$ \\
\hline $14 \cdot 95$ & $\mathrm{C}_{16: 0}$ aldehyde & $0 \cdot 3$ & $0 \cdot 8$ & $1 \cdot 0$ & $0 \cdot 4$ \\
\hline $15 \cdot 00$ & $\mathrm{C}_{15: 0}$ & - & $2 \cdot 5$ & $2 \cdot 5$ & $0 \cdot 6$ \\
\hline $15 \cdot 11$ & iso- $\mathrm{C}_{15: 0} \mathrm{DMA}$ & $10 \cdot 6$ & $1 \cdot 0$ & $0 \cdot 7$ & $1 \cdot 6$ \\
\hline $15 \cdot 48$ & $\mathrm{C}_{15: 0}$ DMA & - & $0 \cdot 3$ & $0 \cdot 2$ & $0 \cdot 1$ \\
\hline $15 \cdot 63$ & iso- $\mathrm{C}_{16: 0}$ & - & $1 \cdot 0$ & $1 \cdot 9$ & $1 \cdot 0$ \\
\hline $15 \cdot 82$ & $\mathrm{C}_{16: 1} \omega 7 c$ & $0 \cdot 1$ & - & - & $0 \cdot 2$ \\
\hline $15 \cdot 91$ & $\mathrm{C}_{16: 1} \omega 5 c$ & - & - & - & - \\
\hline $16 \cdot 00$ & $\mathrm{C}_{16: 0}$ & $4 \cdot 3$ & $15 \cdot 6$ & $19 \cdot 9$ & $10 \cdot 5$ \\
\hline $16 \cdot 47$ & $\mathrm{C}_{16: 0}$ DMA & $1 \cdot 4$ & $1 \cdot 9$ & $2 \cdot 3$ & $2 \cdot 0$ \\
\hline $16 \cdot 63$ & iso- $\mathrm{C}_{17: 0}$ & $8 \cdot 9$ & $17 \cdot 6$ & $17 \cdot 4$ & $23 \cdot 6$ \\
\hline $16 \cdot 72$ & anteiso- $\mathrm{C}_{17: 0}$ & - & $1 \cdot 3$ & $1 \cdot 4$ & $1 \cdot 5$ \\
\hline $17 \cdot 00$ & $\mathrm{C}_{17: 0}$ & - & $0 \cdot 6$ & $0 \cdot 9$ & $0 \cdot 5$ \\
\hline $17 \cdot 11$ & iso- $\mathrm{C}_{17: 0} \mathrm{DMA}$ & $16 \cdot 0$ & $4 \cdot 0$ & $3 \cdot 6$ & $8 \cdot 8$ \\
\hline $17 \cdot 20$ & anteiso- $\mathrm{C}_{17: 0}$ DMA & - & $0 \cdot 2$ & $0 \cdot 2$ & $0 \cdot 6$ \\
\hline $17 \cdot 63$ & iso- $\mathrm{C}_{18: 0}$ & - & - & $0 \cdot 2$ & - \\
\hline $17 \cdot 72$ & $\mathrm{C}_{18: 2} \omega 6,9 c$ & $0 \cdot 4$ & $0 \cdot 2$ & $0 \cdot 2$ & $0 \cdot 4$ \\
\hline $17 \cdot 77$ & $\mathrm{C}_{18: 1} \omega 9 c$ & $1 \cdot 5$ & $0 \cdot 5$ & $0 \cdot 8$ & $1 \cdot 5$ \\
\hline $17 \cdot 82$ & $\mathrm{C}_{18: 1} \omega 7 c$ & - & - & - & $0 \cdot 2$ \\
\hline $18 \cdot 00$ & $\mathrm{C}_{18: 0}$ & $0 \cdot 2$ & $0 \cdot 2$ & $0 \cdot 7$ & $1 \cdot 2$ \\
\hline \multirow[t]{2}{*}{$18 \cdot 64$} & iso- $\mathrm{C}_{19: 0}$ & - & - & - & $0 \cdot 1$ \\
\hline & Total unidentified & $5 \cdot 6$ & $5 \cdot 5$ & $6 \cdot 2$ & $3 \cdot 9$ \\
\hline
\end{tabular}

The G + C content of the genomic DNA of strain RL50JIII ${ }^{\mathrm{T}}$ was $54.5 \mathrm{~mol} \%$ (Table 1 ). A phylogenetic tree constructed on the basis of 16S rRNA gene sequences showed that the closest relative of strain RL50JIII ${ }^{\mathrm{T}}$ was D. solfataricum DSM $14956^{\mathrm{T}}$ (Fig. 1), with which it shared $98 \cdot 7 \%$ sequence similarity in the ARB similarity matrix (which omits insertions and deletions from the pairwise comparison). Strain RL50JIII ${ }^{\mathrm{T}}$ shared a sequence similarity of $96 \cdot 2 \%$ with D. kuznetsovii DSM $6115^{\mathrm{T}}$ in the ARB similarity matrix and of $94 \cdot 2 \%$ with $D$. luciae DSM $12396^{\mathrm{T}}$. The $16 \mathrm{~S}$ rRNA gene sequence of strain RL50JIII ${ }^{\mathrm{T}}$ has a 104-bp insert, which is not present in D. solfataricum or D. kuznetsovii, but which shows $95 \cdot 2 \%$ similarity to that in the $16 \mathrm{~S}$ rRNA gene sequence of $D$. luciae. $16 \mathrm{~S}$ rRNA gene sequence similarities of strain RL50JIII ${ }^{\mathrm{T}}$ with the type strains of D. solfataricum, D. kuznetsovii and D. luciae as calculated with the BIOEDIT program (which includes insertions and deletions in the pairwise comparison) were 92, 90 and $94 \%$, respectively. Levels of DNA-DNA relatedness between strain RL50JIII ${ }^{\mathrm{T}}$ and D. solfataricum DSM $14956^{\mathrm{T}}$, D. kuznetsovii DSM $6115^{\mathrm{T}}$ and D. luciae DSM $12396^{\mathrm{T}}$ were $47 \cdot 4,59 \cdot 5$ and $47 \cdot 8 \%$, respectively, which justifies a novel species designation for strain RL50JIII ${ }^{\mathrm{T}}$ (Wayne et al., 1987).

Strain RL50JIII ${ }^{\mathrm{T}}$ exhibits many features typical of the genus Desulfotomaculum, such as rod-shaped, Gram-positive, motile, spore-forming cells and MK-7 as the major menaquinone. Moreover, the strain is phylogenetically closely related to members of this genus. However, strain RL50JIII $^{\mathrm{T}}$ differs from its closest relatives based on analysis of genomic DNA, higher $\mathrm{G}+\mathrm{C}$ content (Table 1), the ability or inability to use certain electron acceptors and donors (Table 1), and a higher proportion of iso- $\mathrm{C}_{15: 0}$ DMA and iso- $\mathrm{C}_{17: 0}$ DMA and a lower proportion of $\mathrm{C}_{16: 0}$ and iso$\mathrm{C}_{17: 0}$ in the whole-cell fatty acids (Table 2). Based on these phenotypic and genomic differences, strain RL50JIII ${ }^{\mathrm{T}}$ can be assigned as the type strain of a novel species of the genus Desulfotomaculum, for which the name Desulfotomaculum thermosubterraneum sp. nov. is proposed.

\section{Description of Desulfotomaculum thermosubterraneum sp. nov.}

Desulfotomaculum thermosubterraneum (ther.mo.sub.ter. ra'ne.um. Gr. adj. thermos hot; L. adj. neut. subterraneum 


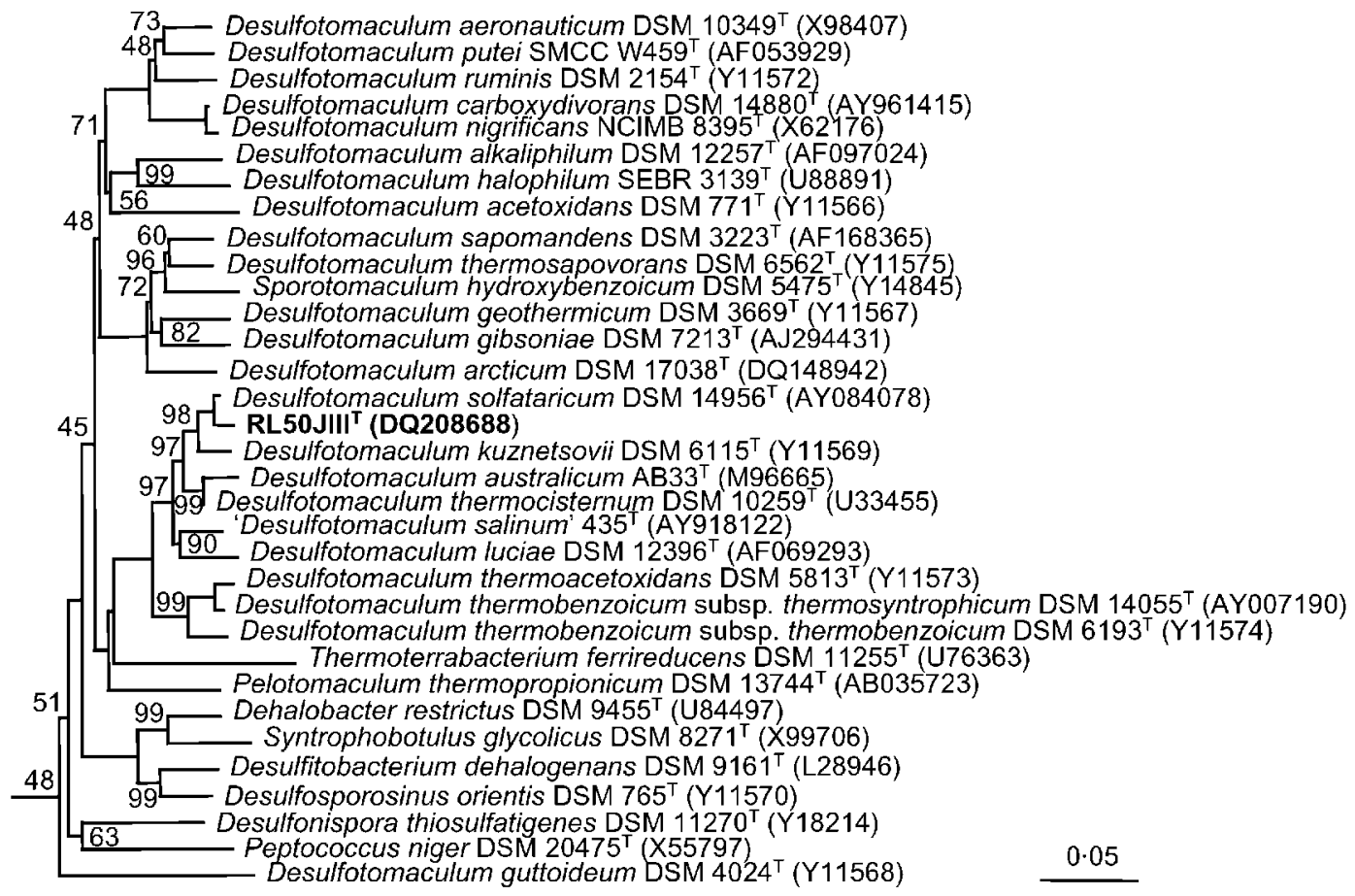

Fig. 1. Phylogenetic tree generated using the distance matrix and neighbour-joining methods based on the 16S rRNA gene sequences of strain RL50JIII (1505 bp between Escherichia coli positions 69 and 1409) and related taxa. Archaeoglobus veneficus (Y10011) was used as the outgroup (not shown). Numbers at nodes represent bootstrap percentages based on 1000 samplings. Bar, 0.05 changes per nucleotide position.

subterranean, underground, below the Earth's surface; thermosubterraneum thermophilic inhabitant of the Earth's subsurface).

Cells are motile, Gram-positive, spore-forming rods $(0 \cdot 8-1 \cdot 0 \times 3-10 \mu \mathrm{m})$. Growth occurs at $50-72{ }^{\circ} \mathrm{C}$ (optimum 61-66 ${ }^{\circ} \mathrm{C}$ ), $\mathrm{pH} 6 \cdot 4-7 \cdot 8$ (optimum $\mathrm{pH} 7 \cdot 2-7 \cdot 4$ ) and $\mathrm{NaCl}$ concentration of $0-1 \cdot 5 \%$ (optimum $0-1 \% \mathrm{NaCl}$ ). Sulfate, sulfite, thiosulfate and elemental sulfur are used as electron acceptors. The following substrates are used as electron donors in the presence of sulfate: $\mathrm{H}_{2}$ in the presence of $\mathrm{CO}_{2}$, alanine, various carboxylic acids and alcohols (see Table 1). Fermentative growth occurs on lactate and pyruvate. The cell wall contains mesodiaminopimelic acid as the diagnostic diamino acid. The major isoprenoid quinone is MK7. Major whole-cell fatty acids are iso- $\mathrm{C}_{15: 0}$, iso- $\mathrm{C}_{17: 0} \mathrm{DMA}$, iso- $\mathrm{C}_{15: 0}$ DMA and iso- $\mathrm{C}_{17: 0}$. The $\mathrm{G}+\mathrm{C}$ content of the DNA is $54 \cdot 4 \mathrm{~mol} \%$.

The type strain, RL50JIII ${ }^{\mathrm{T}}\left(=\right.$ DSM $16057^{\mathrm{T}}=\mathrm{JCM} 13837^{\mathrm{T}}$ ), was isolated from a geothermally active underground mine in Japan.

\section{Acknowledgements}

This work was supported by the Finnish Funding Agency for Technology and Innovation, Outokumpu Oyj, Finland, Finnish Graduate School in Environmental Science and Technology,
Academy of Finland and European Commission (BioMinE contract 500329 and support for working at the DSMZ large-scale facility). Annukka Hämäläinen, Esther Schüler, Anika Vester and Marlen Jando are acknowledged for the technical assistance.

\section{References}

Campbell, L. L. \& Postgate, J. R. (1965). Classification of sporeforming sulfate-reducing bacteria. Bacteriol Rev 29, 359-363.

Cashion, P., Hodler-Franklin, M. A., McCully, J. \& Franklin, M. (1977). A rapid method for base ratio determination of bacterial DNA. Anal Biochem 81, 461-466.

Collins, M. D. \& Jones, D. (1981). Distribution of isoprenoid quinone structural types in bacteria and their taxonomic implications. Microbiol Rev 45, 316-354.

Daumas, S., Cord-Ruwisch, R. \& Garcia, J. L. (1988). Desulfotomaculum geothermicum sp. nov., a thermophilic, fatty acid-degrading, sulfate-reducing bacterium isolated with $\mathrm{H}_{2}$ from geothermal ground water. Antonie van Leeuwenhoek 54, 165-178.

De Ley, J., Cattoir, H. \& Reynaerts, A. (1970). The quantitative measurement of DNA hybridization from renaturation rates. Eur J Biochem 12, 133-142.

Escara, J. F. \& Hutton, J. R. (1980). Thermal stability and renaturation of DNA in dimethyl sulfoxide solutions: acceleration of renaturation rate. Biopolymers 19, 1315-1327.

Fardeau, M.-L., Ollivier, B., Patel, B. K. C., Dwivedi, P., Ragot, M. \& Garcia, J.-L. (1995). Isolation and characterization of a thermophilic sulfate-reducing bacterium, Desulfotomaculum thermosapovorans sp. nov. Int J Syst Bacteriol 45, 218-221. 
Goorissen, H. P., Boschker, H. T. S., Stams, A. J. M. \& Hansen, T. A. (2003). Isolation of thermophilic Desulfotomaculum strains with methanol and sulfite from solfataric mud pools, and characterization of Desulfotomaculum solfataricum sp. nov. Int J Syst Evol Microbiol 53, 1223-1229.

Gregersen, T. (1978). Rapid method for distinction of Gramnegative from Gram-positive bacteria. Eur J Appl Microbiol Biotechnol 5, 123-127.

Groth, I., Schumann, P., Weiss, N., Martin, K. \& Rainey, F. A. (1996). Agrococcus jenesis gen. nov., sp. nov., a new genus of actinomycetes with diaminobutyric acid in the cell wall. Int J Syst Bacteriol 46, 234-239.

Heimbrook, M. E., Wang, W. L. L. \& Campbell, G. (1989). Staining bacterial flagella easily. J Clin Microbiol 27, 2612-2615.

Huß, V. A. R., Festl, H. \& Schleifer, K. H. (1983). Studies on the spectrometric determination of DNA hybridization from renaturation rates. Syst Appl Microbiol 4, 184-192.

Jahnke, K.-D. (1992). Basic computer program for evaluation of spectroscopic DNA renaturation data from Gilford-system 2600 spectrophotometer on a PC/XT/AT type personal computer. J Microbiol Methods 25, 61-73.

Kaksonen, A. H., Plumb, J. J., Robertson, W. J., Franzmann, P. D., Gibson, J. A. E. \& Puhakka, J. A. (2004). Culturable diversity and community fatty acid profiling of sulfate-reducing fluidized-bed reactors treating acidic, metal-containing wastewater. Geomicrobiol J 21, 469-480.

Kaksonen, A. H., Plumb, J. J., Robertson, W. J., Spring, S., Schumann, P., Franzmann, P. D. \& Puhakka, J. A. (2006). Novel thermophilic sulfate-reducing bacteria from a geothermally active underground mine in Japan. Appl Environ Microbiol 72, 3759-3762.

Kämpfer, P. \& Kroppenstedt, R. M. (1996). Numerical analysis of fatty acid patterns of coryneform bacteria and related taxa. Can J Microbiol 42, 989-1005.

Kroppenstedt, R. M. (1985). Fatty acid and menaquinone analysis of actinomycetes and related organisms. In Chemical Methods in Bacterial Systematics, pp. 173-179. Edited by M. Goodfellow \& D. E. Minnikin. London: Academic Press.

Liu, Y., Karnauchow, T. M., Jarrell, K. F., Balkwill, D. L., Drake, G. R., Ringelberg, D., Clarno, R. \& Boone, D. R. (1997). Description of two new thermophilic Desulfotomaculum spp., Desulfotomaculum putei sp. nov., from a deep terrestrial subsurface, and Desulfotomaculum luciae sp. nov., from a hot spring. Int J Syst Bacteriol 47, 615-621.

Love, C. A., Patel, B. K. C., Nichols, P. D. \& Stackebrandt, E. (1993). Desulfotomaculum australicum, sp. nov., a thermophilic sulfatereducing bacterium isolated from the Great Artesian Basin of Australia. Syst Appl Microbiol 16, 244-251.

Mesbah, M., Premachandran, U. \& Whitman, W. (1989). Precise measurement of the $\mathrm{G}+\mathrm{C}$ content of deoxyribonucleic acid by high performance liquid chromatography. Int J Syst Bacteriol 39, 159-167.

Miller, L. T. (1982). Single derivatization method for routine analysis of bacterial whole-cell fatty acid methyl esters, including hydroxy acids. J Clin Microbiol 16, 584-586.

Min, H. \& Zinder, S. H. (1990). Isolation and characterization of a thermophilic sulfate-reducing bacterium Desulfotomaculum thermoacetoxidans sp. nov. Arch Microbiol 153, 399-404.
Monciardini, P., Cavaletti, L., Schumann, P., Rohde, M. \& Donadio, S. (2003). Conexibacter woesei gen. nov., sp. nov., a novel representative of a deep evolutionary line of descent within the class Actinobacteria. Int J Syst Evol Microbiol 53, 569-576.

Nazina, T. N., Ivanova, A. E., Kanchaveli, L. P. \& Rozanova, E. P. (1989). A new sporeforming thermophilic methylotrophic sulfatereducing bacterium, Desulfotomaculum kuznetsovii sp. nov. Microbiology (English translation of Mikrobiologiia) 57, 659-663.

Nazina, T. N., Rozanova, E. P., Belyakova, E. V., Lysenko, A. M., Poltaraus, A. B., Tourova, T. P., Osipov, G. A. \& Belyaev, S. S. (2005). Description of 'Desulfotomaculum nigrificans subsp. salinus' as a new species, Desulfotomaculum salinum sp. nov. Microbiology (English translation of Mikrobiologiia) 74, 567-574.

Nilsen, R. K., Torsvik, T. \& Lien, T. (1996). Desulfotomaculum thermocisternum sp. nov., a sulfate reducer isolated from a hot North Sea oil reservoir. Int J Syst Bacteriol 46, 397-402.

Parshina, S. N., Sipma, J., Nakashimada, Y., Henstra, A. M., Smidt, H., Lysenko, A. M., Lens, P. N. L., Lettinga, G. \& Stams, A. J. M. (2005). Desulfotomaculum carboxydivorans sp. nov., a novel sulfatereducing bacterium capable of growth at $100 \%$ CO. Int J Syst Evol Microbiol 55, 2159-2165.

Pikuta, E., Lysenko, A., Suzina, N., Osipov, G., Kuznetsov, B., Tourova, T., Akimenko, V. \& Laurinavichius, K. (2000). Desulfotomaculum alkaliphilum sp. nov., a new alkaliphilic, moderately thermophilic, sulfate-reducing bacterium. Int J Syst Evol Microbiol 50, 25-33.

Plugge, C. M., Balk, M. \& Stams, A. J. M. (2002). Desulfotomaculum thermobenzoicum subsp. thermosyntrophicum subsp. nov., a thermophilic, syntrophic, propionate-oxidizing, spore-forming bacterium. Int J Syst Evol Microbiol 52, 391-399.

Rhuland, L. E., Work, E., Denman, R. F. \& Hoare, D. S. (1955). The behaviour of the isomers of $\alpha, \varepsilon$-diaminopimelic acid on paper chromatograms. J Am Chem Soc 77, 4844-4846.

Stookey, L. L. (1970). Ferrozine - a new spectrophotometric reagent for iron. Anal Chem 42, 779-781.

Tamaoka, J. \& Komagata, K. (1984). Determination of DNA base composition by reversed-phase high-performance liquid chromatography. FEMS Microbiol Lett 25, 125-128.

Tasaki, M., Kamagata, Y., Nakamura, K. \& Mikami, E. (1991). Isolation and characterization of a thermophilic benzoate-degrading, sulfate-reducing bacterium, Desulfotomaculum thermobenzoicum sp. nov. Arch Microbiol 155, 348-352.

Vandieken, V., Knoblauch, C. \& Jorgensen, B. B. (2006). Desulfotomaculum arcticum sp. nov., a novel spore-forming, moderately thermophilic, sulfate-reducing bacterium isolated from a permanently cold fjord sediment of Svalbard. Int $J$ Syst Evol Microbiol 56, 687-690.

Wayne, L. G., Brenner, D. J., Colwell, R. R. \& 9 other authors (1987). Report of the ad hoc committee on reconciliation of approaches to bacterial systematics. Int J Syst Bacteriol 37, 463-464.

Werkman, C. H. \& Weaver, H. J. (1927). Studies in the bacteriology of sulphur stinker spoilage of canned sweet corn. Iowa State Coll J Sci 2, 57-67. 